\title{
Genetic analysis of Aphaniidae Hoedeman, 1949 (Teleostei: Cyprinodontiformes) family in Anatolia ${ }^{\left[{ }^{*}\right]}$
}

\author{
Mehmet KUYUMCU $^{1} \quad$ İsmail AKSU ${ }^{1} \quad$ Yusuf BEKTAŞ ${ }^{2 *}$ \\ ${ }^{1}$ Recep Tayyip Erdogan University, The Faculty of Fisheries and Aquatic Sciences, Rize, Turkey \\ ${ }^{2}$ Recep Tayyip Erdogan University, The Faculty of Arts and Sciences, Biology, Rize, Turkey
}

Geliş/Received: 30.11 .2021

Kabul/Accepted: 07.12.2021

Yayın/Puplished: 31.12 .2021

How to cite: Kuyumcu, M., Aksu, İ. \& Bektaş, Y. (2021). Genetic analysis of Aphaniidae Hoedeman, 1949 (Teleostei: Cyprinodontiformes) family in Anatolia. J. Anatolian Env. and Anim. Sciences, 6(4), 627-634.

Atıf yapmak için: Kuyumcu, M., Aksu, İ. \& Bektaş, Y. (2021). Anadolu'daki Aphaniidae Hoedeman, 1949 (Teleostei: Cyprinodontiformes) ailesinin genetik analizi. Anadolu Çev. ve Hay. Dergisi, 6(4), 627-634.

(D): https://orcid.org/0000-0003-3162-1179 (iD): https://orcid.org/0000-0002-2104-9888 *[D: https://orcid.org/0000-0002-8367-9746

*Corresponding author:

Yusuf BEKTAS

Recep Tayyip Erdogan University, The

Faculty of Arts and Sciences, Biology, Rize, Turkey

凶: yusuf.bektas.tr@gmail.com
Abstract: We tested the mitochondrial DNA cytochrome b gene-based (1065 bp.) phylogeny and genetic diversity of tooth-carp fish (Aphaniidae Hoedeman, 1949), many of which are endemic, with a very high species diversity in Anatolia. A total of 107 individuals were studied from 29 stations belonging to 19 Aphaniid species and forty-four haplotypes were identified, all of which were species-specific.

The phylogenetic relationships generated by neighbor joining, maximum likelihood and maximum parsimony methods are fully compatible with each other. The generally well supported phylogenetic tree results and genetic distance results supported a structure divided into four lineages corresponding to four genera (Anatolichthys, Paraphanius, Aphanius, and Kosswigichthys). The genetic distance between these four lineages indicated a significant value ranging from $16.6 \%$ (between Aphanius and Anatolichthys) to $23.1 \%$ (between Aphanius and Paraphanius). Interspecies genetic distances ranged from $1.9 \%$ (between $P$. boulengeri and $P$. similis) to $24.52 \%$ (between $A$. villwocki and $P$. mentoides), except for two interspecies distances (A. fontinalis - A. sureyanus, $0.13 \%$ and A. maeandricus $-A$. irregularis, $0.57 \%$ ).

Our results agree with previous studies of the Anatolian Aphaniidae family, which showed a diversification pattern shaped by Pliocene orogenic events. The present results indicate that mitochondrial DNA cytochrome $b$ gene sequences are effective for Aphaniidae species identification and phylogenetic analysis.

Keywords: Anatolia, cytochrome b, phylogeny, tooth-carp.

\section{Anadolu'daki Aphaniidae Hoedeman, 1949 (Teleostei: Cyprinodontiformes) ailesinin genetik analizi}

Öz: Anadolu'da çok yüksek tür çeşitliliğine sahip, çoğu endemik olan dişli sazancık balıklarının (Aphaniidae Hoedeman, 1949) mitokondri DNA sitokrom b genine (1065 bç.) dayalı filogenisini ve genetik çeşitliliğini test ettik. 19 Aphaniid türüne ait 29 istasyondan toplam 107 örnek incelendi ve türe özgü olan 44 haplotip tanımlandı.

Komşu birleştirme, maksimum olabilirlik ve maksimum tutumluluk yöntemleriyle oluşturulan filogenetik ilişkiler birbiriyle tam uyumlu sonuçlar verdi. Genel olarak iyi desteklenen filogenetik ağaç sonuçları ve genetik uzaklık sonuçları, dört cinse (Anatolichthys, Paraphanius, Aphanius, and Kosswigichthys) karşıllk gelen dört soydan oluşan bir yapıyı destekledi. Bu dört soy grubu arasındaki genetik mesafe \%16,6 (Aphanius ve Anatolichthys) ile \%23,1 (Aphanius ve Paraphanius) arasında değişen ciddi bir değer gösterdi. Türler arası genetik mesafeler iki tür grubu (A. fontinalis - A. sureyanus: \%0.1 ve A. maeandricus - A. irregularis: \%0.6) dişında \%2.8 ( $P$. boulengeri ve P.similis) ile $\% 24.5$ arasında (A. villwocki ile $P$. mentoides) arasinda değişmektedir.

*Sorumlu yazar:

Yusuf BEKTAS

Recep Tayyip Erdoğan Üniversitesi, Fen-

Edebiyat Fakültesi, Biyoloji, Rize, Türkiye.

凶: yusuf.bektas.tr@gmail.com
Sonuçlarımız aynı zamanda, Pliyosen orojenik olaylarıyla şekillenen bir çeşitlenme modeli gösteren Anadolu Aphaniidae familyasının önceki çalışmalarıyla da uyumludur. Mevcut sonuçlar, mitokondriyal DNA sitokrom b gen dizilerinin Aphaniidae türlerinin tanımlanması ve filogenetik analizi için etkili olduğunu göstermektedir.

Anahtar kelimeler: Anadolu, dișli sazancık, filogeni, sitokrom b. 


\section{INTRODUCTION}

Members of the family Aphaniidae Hoedeman, 1949, known as tooth-carp fish, are naturally distributed in coastal (brackish and euryhaline waters) and inland waters (creeks, streams, rivers, lakes, ponds, and marshes). The aphaniids are distributed in the coastal regions of the Mediterranean, the Gir Peninsula of northwestern India, the Red Sea, and Persian Gulf, and northeastern Somalia, and are among the most species-rich families in the order Cyprinodontiformes (Wildekamp, 1993; Coad, 2000; Gholami et al., 2014; Reichenbacher et al., 2007; Teimori et al., 2018; Esmaeili et al., 2020). The highest species diversity in aphaniids is found in the Central Anatolian and Iranian plateau (Coad, 2000). In fact, the Central Anatolian geography is considered the center of diversity of the aphaniids (Wildekamp et al., 1999). Members of the aphaniids are relict species and are considered to be the oldest known secondary freshwater fishes in Anatolia (Hrbek \& Meyer, 2003). The distribution area of the family coincides with Tethys and Paratethys covering most of Europe from the early Eocene to Miocene (Hrbek \& Meyer, 2003). The tooth-carp fish is considered to be a remnant of the Tethys, thought to have evolved from a common ancestor scattered around the Tethys Sea (Kosswig, 1967; Por \& Dimentman, 1989). This hypothesis is supported by molecular analysis of mitochondrial DNA genes (Hrbek \& Meyer, 2003).

Members of the Aphaniidae thought to have diversified due to geological events in the ancient Tethys region and the effect of ecological factors, were defined within a single genus Aphanius until recent studies. Hrbek et al. (2002), and Hrbek and Meyer (2003) mentioned the presence of six sublineages in analyses based on mitochondrial DNA genes (12S, $16 \mathrm{~S}$ ribosomal RNA, NADH I and II). Subsequently, Esmaeili et al. (2020) stated that three lineages should be identified as Aphanius, Aphaniops and Paraphanius based on DNA barcoding. Finally, Freyhof and Yoğurtçuoğlu (2020) suggested that monophyletic species groups that emerge in phylogenetic analyses should be evaluated together with morphological characters and defined into eight lineages (Anatolichthys, Kosswigichthys, Aphanius, Aphaniops, Paraphanius, Tellia, Esmaeilius and Apricaphanius). Today, the aphaniids are represented by eight genera.

Freyhof and Yoğurtçuoğlu (2020) had already reported that 21 species of aphaniids are distributed in Anatolia and many species of toothedcarp species are threatened. According to the Red List of Threatened Species of the International Union for Conservation of Nature (IUCN, 2021), ten Anatolian aphaniid species are listed. Three of them are critically endangered (CR), one species endangered (EN), one species nearly threatened (NT), one species extinct (EX), and four other least concern species (LC). In addition, eleven species were not evaluated (NE).

The aim of this study was to determine the genetic structure and phylogenetic relationships within and among Anatolian Aphaniidae species, most of which are endangered, using mtDNA cytochrome $b$ gene sequences.

\section{MATERIAL AND METHOD}

Sampling: A total of 107 individuals from Aphaniidae distributed in Anatolia were sampled at 29 stations using electroshockers (Table 1). The collected samples were first anesthetized with tricaine methane sulfonate solution (MS222), then their species level were identified according to taxonomic keys and labeled, and fixed with $96 \%$ ethyl alcohol. Except for the DNA sequence analysis, all laboratory work was carried out in the genetics laboratory of the Faculty of Fisheries of Recep Tayyip Erdogan University.

DNA Extraction, PCR Amplification and DNA Sequencing: Genomic DNA was extracted from the ethanolfixed fin clips using DNeasy Blood \& Tissue Kit (Qiagen, USA) following the manufacturer's protocol carried out in the Qiacube Automated DNA purification system. The DNA concentration and purity of each sample were assessed by spectrophotometry (Nanodrop, 2000/c, Thermo Scientific, USA), while the integrity was assessed by $1 \%$ TAE-agarose gel electrophoresis containing $0.5 \mathrm{mg} / \mathrm{l} \mathrm{EtBr}$.

The vertebrate mtDNA cytochrome $\mathrm{b}(c y t b)$ gene was amplified using L14724: 5'GTGACTTGAAAAACCACCGTTG-3'; H15915: 5'CAACGATCTCCGGTTTACA AGAC-3' primers (Anderson et al., 1981). PCR reactions were carried out in $50 \mu \mathrm{l}$ total volume containing $5 \mu \mathrm{l}$ of $10 \mathrm{X}$ reaction buffer; 5 $\mu 1 \mathrm{MgCl}_{2}(25 \mathrm{mM}) ; 8 \mu \mathrm{l}$ of dNTPmix $(10 \mathrm{mM}) ; 1 \mu \mathrm{l}$ of forward primer (10 pmol); $1 \mu \mathrm{l}$ of reverse primer $(10 \mathrm{pmol})$; $0.2 \mu 1$ of Taq DNA polymerase (1 U); $3 \mu$ of DNA template (50 ng/ $\mu \mathrm{l}$ ); and $26.8 \mu \mathrm{l}$ sterilized pure water. PCR reactions were performed using a gradient thermal cycler Biorad T100 ${ }^{\mathrm{TM}}$ (Bio-Rad, Hercules, USA). The PCR condition was as follows: 1 cycle at $95^{\circ} \mathrm{C}$ for $3 \mathrm{~min}$ for initial denaturation, followed by 35 cycles denaturation at $95^{\circ} \mathrm{C}$ for $30 \mathrm{~s}$, annealing at $55^{\circ} \mathrm{C}$ for $30 \mathrm{~s}$, extension at $72^{\circ} \mathrm{C}$ for $1 \mathrm{~min}$, ended up with a final extension for one cycle at $72^{\circ} \mathrm{C}$ for 5 min. Assessment of concentrations and sizes of PCR products were performed both spectrophotometrically and by $1.2 \%$ TAE-agarose gel electrophoresis containing 0.5 $\mathrm{mg} / \mathrm{l} \mathrm{EtBr}$. The amplicons were visualized on UV QuantumCapt ST4 system (Vilber Lourmat, France).

PCR products were directly sequenced in both directions using the L14724 and H15915 primers on an ABI 
3730XL DNA Analyzer (Applied Biosystems) by Macrogen Inc. (Amsterdam, The Netherlands).

Molecular Data Analysis: The vertebrate mtDNA cytb raw sequences were aligned by Clustal-W (Thompson et al., 1994) and edited manually with Bioedit 7.0.0 (Hall, 1999). The number of haplotype, haplotype and nucleotide diversity were calculated using the software DNASP v.5.10.01 (Librado \& Rozas, 2009). The number of polymorphic sites, the nucleotid number of conserved, variable and parsimonic informative, the nucleotide composition, number of transitions and transversions were calculated using the MEGA version X (Kumar et al., 2018). Average inter-specific and intra-specific, average genetic distances were calculated using Kimura two-parameter model (K2P; Kimura, 1980) implemented in MEGA version X (Kumar et al., 2018).

Phylogenetic analyses were performed by using neighbour joining (NJ), maximum parsimony (MP) and maximum likelihood (ML) analyses. NJ trees were generated using MEGA X (Kumar et al., 2018) with 1000 bootstrap replicates according to $\mathrm{K} 2 \mathrm{P}+\mathrm{G}$ method. MP analysis was performed using PAUP* $4.0 \mathrm{~b} 10$ (Swofford, 2003) with heuristic search, TBR branch-swapping, 1000 bootstrap replicates (Felsenstein, 1985), random addition sequence with 10 replicates. According to the Akaike information criterion (AIC), jModeltest v.0.1.1 (Posada, 2008) selected the TN93+G+I as the best model evolution for the cytb dataset. ML analysis with 100 bootstrap replicates implemented in PhyML ver. 2.4.4 (Guindon \& Gascuel, 2003). To evaluate the evolutionary relationships of Aphaniidae species, Cyprinodon variegatus (GenBank accession number: NC028088) was used as outgroup for rooting.

\section{RESULTS}

A total of 107 Aphaniidae specimens were collected from 29 stations during the field studies. A total of 19 species belonging to four genera (Aphanius, Kosswigichthys, Anatolichthys and Paraphanius) from the Aphaniidae family were identified based on morphological diagnostic keys. Information about the study material is given in Table 1. From Aphaniidae genera in Anatolia, Aphanius and Kosswigichthys are represented by one species, while Anatolichthys and Paraphanius are represented by 12 and 5 species, respectively.

Table 1. Sampling and location information with haplotype code.

\begin{tabular}{|c|c|c|c|c|}
\hline Species & Locations & Coordinates & Sample Number & Haplotype Code \\
\hline Aphanius fasciatus & Tuz Lake, Karataş, Adana & $36^{\circ} 42^{\prime} 20.8^{\prime \prime} \mathrm{N} 35^{\circ} 03^{\prime} 08.2^{\prime \prime} \mathrm{E}$ & 3 & OL739303 \\
\hline Kosswigichthys asquamatus & Behramaz Stream, Maden, Elazığ & $38^{\circ} 28^{\prime} 27.5^{\prime \prime N} 39^{\circ} 33^{\prime} 26.6^{\prime \prime E}$ & 5 & OL739304- OL739307 \\
\hline Anatolichthys anatoliae & İnsuyu Stream, Cihanbeyli, Konya & $38^{\circ} 43^{\prime} 22.2^{\prime \prime} \mathrm{N} 32^{\circ} 43^{\prime} 02.7^{\prime \prime} \mathrm{E}$ & 6 & OL739308- OL739311 \\
\hline Anatolichthys danfordii & Yay Lake, Develi, Kayseri & $38^{\circ} 19^{\prime} 47.1^{\prime \prime} \mathrm{N} 35^{\circ} 17^{\prime} 40.4^{\prime \prime} \mathrm{E}$ & 6 & OL739313 \\
\hline \multirow[t]{2}{*}{ Anatolichthys fontinalis } & Salda Lake, Yeşilova, Burdur & $37^{\circ} 31^{\prime} 35.0^{\prime \prime} \mathrm{N} 29^{\circ} 40^{\prime} 29.8^{\prime \prime} \mathrm{E}$ & 4 & OL739314 \\
\hline & Karaevli Spring, Burdur & $37^{\circ} 34^{\prime} 46.7^{\prime \prime N ~} 30^{\circ} 24^{\prime} 02.5^{\prime \prime} \mathrm{E}$ & 2 & OL739314 \\
\hline \multirow{2}{*}{ Anatolichthys iconii } & Eğirdir Lake, Isparta & $37^{\circ} 50^{\prime} 48.5^{\prime \prime} \mathrm{N} 30^{\circ} 52^{\prime} 14.9^{\prime \prime} \mathrm{E}$ & 2 & OL739315 \\
\hline & Yeşilyurt Village, Sütçüler, Isparta & $37^{\circ} 31^{\prime} 57.5^{\prime \prime} \mathrm{N} 30^{\circ} 51^{\prime} 53.0^{\prime \prime} \mathrm{E}$ & 2 & OL739315 \\
\hline Anatolichthys irregularis & Aksu Stream, Kaklık, Denizli & $37^{\circ} 50^{\prime} 08.3^{\prime \prime} \mathrm{N} 29^{\circ} 26^{\prime} 02.6^{\prime \prime} \mathrm{E}$ & 2 & OL739316 \\
\hline Anatolichthys maeandricus & Su çıkan Stream, Dinar, Afyon & $38^{\circ} 04^{\prime} 54.7^{\prime \prime N} 30^{\circ} 09^{\prime} 35.3^{\prime \prime E}$ & 3 & OL739317 \\
\hline \multirow[t]{2}{*}{ Anatolichthys marassantensis } & Hirfanlı Dam, Kırşehir & $39^{\circ} 01^{\prime} 59.5^{\prime \prime} \mathrm{N} 33^{\circ} 59^{\prime} 24.6^{\prime \prime} \mathrm{E}$ & 3 & OL739318 \\
\hline & Tuz Lake, Şerflikoçhisar, Ankara & $38^{\circ} 54^{\prime} 11.8^{\prime \prime} \mathrm{N} 33^{\circ} 24^{\prime} 58.6^{\prime \prime} \mathrm{E}$ & 4 & OL739318 \\
\hline \multirow[t]{4}{*}{ Anatolichthys meridionalis } & Çataloluk Stream, Sögüt, Burdur & $37^{\circ} 01^{\prime} 31.1^{\prime \prime} \mathrm{N} 29^{\circ} 50^{\prime} 12.5^{\prime \prime} \mathrm{E}$ & 3 & OL739319-OL739321 \\
\hline & Gavurçay Stream, Elmalı, Antalya & $36^{\circ} 38^{\prime} 21.8^{\prime \prime} \mathrm{N} 29^{\circ} 45^{\prime} 13.6^{\prime \prime} \mathrm{E}$ & 4 & OL739322-OL739323 \\
\hline & Akçay Stream, Elmalı, Antalya & $36^{\circ} 37^{\prime} 53.2^{\prime \prime} \mathrm{N} 29^{\circ} 49^{\prime} 42.5^{\prime \prime} \mathrm{E}$ & 6 & OL739322, OL739323, OL739326 \\
\hline & Aslanlı Stream, Gölhisar, Burdur & $37^{\circ} 09^{\prime} 15.9^{\prime \prime} \mathrm{N} 29^{\circ} 34^{\prime} 34.5^{\prime \prime} \mathrm{E}$ & 2 & OL739327 \\
\hline Anatolichthys sureyanus & Eren Stream, Burdur Lake, Burdur & $37^{\circ} 37^{\prime} 45.5^{\prime \prime} \mathrm{N} 30^{\circ} 04^{\prime} 45.6^{\prime \prime} \mathrm{E}$ & 9 & OL739328-OL739329 \\
\hline Anatolichthys transgrediens & Acı Lake, Başmakçı, Afyon & $37^{\circ} 49^{\prime} 46.7^{\prime \prime} \mathrm{N} 29^{\circ} 53^{\prime} 33.9^{\prime \prime} \mathrm{E}$ & 2 & OL739330-OL739331 \\
\hline \multirow[t]{3}{*}{ Anatolichthys villwocki } & Özyurt, Polatlı, Ankara & $39^{\circ} 12^{\prime} 38.5^{\prime \prime} \mathrm{N} 32^{\circ} 04^{\prime} 12.8^{\prime \prime} \mathrm{E}$ & 3 & OL739332 \\
\hline & Seydi Stream, Çifteler, Eskişehir & $39^{\circ} 24^{\prime} 46.2^{\prime \prime} \mathrm{N} 31^{\circ} 07^{\prime} 43.3^{\prime \prime} \mathrm{E}$ & 9 & OL739333-OL739335 \\
\hline & Beşgöz Pond, Sarayönü, Konya & $38^{\circ} 16^{\prime} 23.9^{\prime \prime} \mathrm{N} 32^{\circ} 20^{\prime} 45.9^{\prime \prime} \mathrm{E}$ & 1 & OL739333 \\
\hline Anatolichthys saldae & Salda Lake, Yeşilova, Burdur & $37^{\circ} 31^{\prime} 35.0^{\prime \prime N} 29^{\circ} 40^{\prime} 29.8^{\prime \prime} \mathrm{E}$ & 4 & OL739336-OL739339 \\
\hline Paraphanius alexandri & Çöçelli, Pazarcık, Kahramanmaraş & 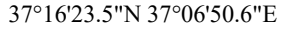 & 2 & OL739340 \\
\hline Paraphanius orontis & Asi River, Samandağ, Hatay & $36^{\circ} 04^{\prime} 57.1 " \mathrm{~N} 35^{\circ} 57^{\prime} 07.8^{\prime \prime} \mathrm{E}$ & 2 & OL739341 \\
\hline Paraphanius boulengeri & Gölbaşı Lake, Adıyaman & $37^{\circ} 48^{\prime} 00.6^{\prime \prime} \mathrm{N} 37^{\circ} 38^{\prime} 40.0^{\prime \prime} \mathrm{E}$ & 4 & OL739342 \\
\hline Paraphanius similis & Bağlı Village, Aksaray & $38^{\circ} 16^{\prime} 29.9^{\prime \prime} \mathrm{N} 34^{\circ} 03^{\prime} 34.4^{\prime \prime} \mathrm{E}$ & 2 & OL739343 \\
\hline \multirow[t]{3}{*}{ Paraphanius mentoides } & Nemrut Lake, Tatvan, Bitlis & $38^{\circ} 37^{\prime} 07.6^{\prime \prime} \mathrm{N} 42^{\circ} 12^{\prime} 39.1 " \mathrm{E}$ & 5 & OL739344 \\
\hline & Kırkgöz Lake, Döşemealtı, Antalya & $37^{\circ} 04^{\prime} 32.0^{\prime \prime} \mathrm{N} 30^{\circ} 34^{\prime} 14.4^{\prime \prime} \mathrm{E}$ & 2 & OL739344 \\
\hline & Düden Stream, Kepez, Antalya & $36^{\circ} 57^{\prime} 11.9^{\prime \prime} \mathrm{N} 30^{\circ} 44^{\prime} 26.0^{\prime \prime} \mathrm{E}$ & 5 & OL739345-OL739346 \\
\hline Total & & & 107 & 44 \\
\hline
\end{tabular}

The mtDNA $c y t b$ gene of 107 individuals belonging to the Aphaniidae family was amplified and sequenced 1065 nucleotide without insertion, deletion, gap and stop codon. The cytb sequences were deposited in GenBank under the accession numbers OL739303OL739346. The average nucleotide composition for 107 cytb sequences is $30.8 \% \mathrm{~T}, 28.8 \% \mathrm{C}, 25.0 \% \mathrm{~A}$ and $15.5 \%$ G. For Aphaniidae species, $683(64.1 \%)$ of the mtDNA cytb nucleotide sequences were conserved, 382 (35.9\%) variable and $382(35.9 \%)$ parsimonic informative. For polymorphic nucleotide positions, 92 transitions and 39 transversions were determined, and the ratio of transition (Ti) to transversion ( $\mathrm{Tv}$ ) was calculated as $\mathrm{Ti} / \mathrm{Tv}=2.36$.

A total of 44 haplotypes of 19 Aphaniidae species distributed in Anatolia were determined. Most of the species are represented by only 1 haplotype, while Anatolichthys meridionalis is represented by 9 haplotypes. 
The number of haplotypes, the haplotype diversity and nucleotide diversity values are shown in Table 2.

The haplotype diversity of Anatolichthys saldae and Anatolichthys transgrediens populations were the highest $(\mathrm{Hd}=1.000)$, compared with the lowest haplotype diversity of Aphanius fasciatus, Anatolichthys fontinalis, Anatolichthys iconii, Anatolichthys irregularis, Anatolichthys maeandricus, Anatolichthys marassantensis, Paraphanius alexandri, Paraphanius boulengeri, Paraphanius orontis and Paraphanius similis $(\mathrm{Hd}=0.0000)$. The nucleotide diversity of Anatolichthys meridionalis was the highest $(\mathrm{Pi}=0.0086)$, compared with the lowest nucleotide diversity of Aphanius fasciatus, Anatolichthys fontinalis, Anatolichthys iconii, Anatolichthys irregularis, Anatolichthys maeandricus, Anatolichthys marassantensis, Paraphanius alexandri, Paraphanius boulengeri, Paraphanius orontis and Paraphanius similis $(\mathrm{Pi}=0.0000)$ (Table 2).

Table 2. Sample size (N), number of haplotypes (HN), haplotype diversity (Hd) and nucleotide diversity (Pi) for Aphaniidae species.

\begin{tabular}{lcccc}
\hline Species & N & HN & Hd & Pi \\
\hline Aphanius fasciatus & 3 & 1 & 0.0000 & 0.0000 \\
Kosswigichthys asquamatus & 5 & 4 & 0.9000 & 0.0030 \\
Anatolichthys anatoliae & 6 & 4 & 0.8000 & 0.0020 \\
Anatolichthys danfordii & 6 & 2 & 0.5333 & 0.0005 \\
Anatolichthys fontinalis & 6 & 1 & 0.0000 & 0.0000 \\
Anatolichthys iconii & 4 & 1 & 0.0000 & 0.0000 \\
Anatolichthys irregularis & 2 & 1 & 0.0000 & 0.0000 \\
Anatolichthys maeandricus & 3 & 1 & 0.0000 & 0.0000 \\
Anatolichthys marassantensis & 7 & 1 & 0.0000 & 0.0000 \\
Anatolichthys meridionalis & 15 & 9 & 0.8857 & 0.0086 \\
Anatolichthys sureyanus & 9 & 2 & 0.5000 & 0.0005 \\
Anatolichthys transgrediens & 2 & 2 & 1.0000 & 0.0009 \\
Anatolichthys villwocki & 13 & 4 & 0.7949 & 0.0020 \\
Anatolichthys saldae & 4 & 4 & 1.0000 & 0.0020 \\
Paraphanius alexandri & 2 & 1 & 0.0000 & 0.0000 \\
Paraphanius orontis & 2 & 1 & 0.0000 & 0.0000 \\
Paraphanius boulengeri & 4 & 1 & 0.0000 & 0.0000 \\
Paraphanius similis & 2 & 1 & 0.0000 & 0.0000 \\
Paraphanius mentoides & 12 & 3 & 0.6212 & 0.0013 \\
\hline TOTAL & $\mathbf{1 0 7}$ & $\mathbf{4 4}$ & & \\
\hline
\end{tabular}

The intergeneric distances among Aphaniidae genera ranged from $23.1 \%$ (between Aphanius and
Paraphanius) and 16.6\% (between Aphanius and Anatolichthys) (Table 3). The intrageneric distance within Aphaniidae genera is $0 \%$ (Aphanius) and $8.9 \%$ (Anatolichthys) (Table 3).

Table 3. Average intergeneric and intrageneric distance for Aphaniidae family. The parts marked in gray indicate average genetic distances within genera.

\begin{tabular}{llllll}
\hline & Genera & $\mathbf{1}$ & $\mathbf{2}$ & $\mathbf{3}$ & $\mathbf{4}$ \\
\hline $\mathbf{1}$ & Aphanius & 0.000 & & & \\
$\mathbf{2}$ & Kosswigichthys & 0.183 & 0.003 & & \\
$\mathbf{3}$ & Anatolichthys & 0.166 & 0.169 & 0.089 & \\
$\mathbf{4}$ & Paraphanius & 0.231 & 0.219 & 0.222 & 0.041 \\
\hline
\end{tabular}

For $c y t b$, intraspecies and interspecies genetic distance values are given in Table 4. The interspecific genetic distances among Aphaniidae species ranged from $0.1 \%$ (between Anatolichthys fontinalis and Anatolichthys sureyanus) and $24.52 \%$ (between $A$. villwocki and $P$. mentoides) (Table 4). On the other hand, the intraspecific genetic distances within Aphaniidae species ranged from 0\% (Aphanius fasciatus, Anatolichthys marassantensis, Anatolichthys iconii, Anatolichthys sureyanus, Anatolichthys fontinalis, Anatolichthys maeandricus, Anatolichthys irregularis, Paraphanius boulengeri, Paraphanius similis, Paraphanius mentoides, Paraphanius orontis, Paraphanius alexandri and) and 0.9\% (Anatolichthys meridionalis) Table 4.

Phylogenetic analyses were performed with distance-based (NJ) and character-based (ML and MP) methods based on the mtDNA cytb gene. The tree topologies produced by the three methods were generally compatible with each other. Anatolian Aphaniids, Anatolichthys, Paraphanius, Aphanius, and Kosswigichthys genera, constructed four lineages in tree topology. The phylogenetic trees recovered by NJ, MP and ML methods yielded identical topologies with high bootstrap supports (51-100\% for NJ, MP, and ML) (Figure 1).

Table 4. Intraspecies and interspecies average genetic distance values of Aphaniidae family. The parts marked in gray indicate average genetic distances within species.

\begin{tabular}{|c|c|c|c|c|c|c|c|c|c|c|c|c|c|c|c|c|c|c|c|c|}
\hline & Species & 1 & 2 & 3 & 4 & 5 & 6 & 7 & 8 & 9 & 10 & 11 & 12 & 13 & 14 & 15 & 16 & 17 & 18 & 19 \\
\hline 1 & A. fasciatus & 0.000 & & & & & & & & & & & & & & & & & & \\
\hline 2 & K. asquamatus & 0.183 & 0.003 & & & & & & & & & & & & & & & & & \\
\hline 3 & A. anatoliae & 0.169 & 0.165 & 0.002 & & & & & & & & & & & & & & & & \\
\hline 4 & A. marassantensis & 0.156 & 0.165 & 0.105 & 0.000 & & & & & & & & & & & & & & & \\
\hline 5 & A. iconii & 0.173 & 0.155 & 0.089 & 0.114 & 0.000 & & & & & & & & & & & & & & \\
\hline 6 & A. villwocki & 0.165 & 0.166 & 0.107 & 0.113 & 0.109 & 0.002 & & & & & & & & & & & & & \\
\hline 7 & A. transgrediens & 0.180 & 0.179 & 0.104 & 0.121 & 0.062 & 0.115 & 0.001 & & & & & & & & & & & & \\
\hline 8 & A. meridionalis & 0.152 & 0.165 & 0.097 & 0.100 & 0.082 & 0.102 & 0.105 & 0.009 & & & & & & & & & & & \\
\hline 9 & A. fontinalis & 0.174 & 0.176 & 0.105 & 0.123 & 0.065 & 0.116 & 0.077 & 0.093 & 0.000 & & & & & & & & & & \\
\hline 10 & A. maeandricus & 0.180 & 0.177 & 0.092 & 0.102 & 0.101 & 0.114 & 0.117 & 0.103 & 0.115 & 0.000 & & & & & & & & & \\
\hline 11 & A. danfordii & 0.161 & 0.170 & 0.102 & 0.077 & 0.107 & 0.109 & 0.121 & 0.101 & 0.105 & 0.109 & 0.001 & & & & & & & & \\
\hline 12 & A. irregularis & 0.183 & 0.178 & 0.093 & 0.102 & 0.104 & 0.114 & 0.119 & 0.106 & 0.118 & 0.006 & 0.109 & 0.000 & & & & & & & \\
\hline 13 & A. sureyanus & 0.173 & 0.174 & 0.104 & 0.122 & 0.063 & 0.115 & 0.075 & 0.092 & 0.001 & 0.116 & 0.106 & 0.119 & 0.000 & & & & & & \\
\hline 14 & A. saldae & 0.172 & 0.172 & 0.107 & 0.127 & 0.061 & 0.121 & 0.070 & 0.093 & 0.031 & 0.121 & 0.110 & 0.123 & 0.030 & 0.002 & & & & & \\
\hline 15 & P. boulengeri & 0.227 & 0.220 & 0.206 & 0.220 & 0.221 & 0.229 & 0.221 & 0.219 & 0.222 & 0.229 & 0.214 & 0.229 & 0.224 & 0.222 & 0.000 & & & & \\
\hline 16 & P. similis & 0.227 & 0.219 & 0.203 & 0.224 & 0.214 & 0.230 & 0.221 & 0.214 & 0.220 & 0.232 & 0.216 & 0.235 & 0.222 & 0.221 & 0.028 & 0.000 & & & \\
\hline 17 & P. mentoides & 0.237 & 0.223 & 0.212 & 0.218 & 0.223 & 0.245 & 0.217 & 0.225 & 0.222 & 0.222 & 0.217 & 0.228 & 0.223 & 0.217 & 0.065 & 0.071 & 0.001 & & \\
\hline 18 & P. orontis & 0.215 & 0.199 & 0.193 & 0.207 & 0.206 & 0.218 & 0.199 & 0.208 & 0.213 & 0.212 & 0.215 & 0.212 & 0.214 & 0.208 & 0.059 & 0.076 & 0.064 & 0.000 & \\
\hline 19 & P. alexandri & 0.222 & 0.216 & 0.206 & 0.214 & 0.228 & 0.228 & 0.221 & 0.216 & 0.221 & 0.230 & 0.217 & 0.230 & 0.222 & 0.224 & 0.019 & 0.032 & 0.065 & 0.062 & 0.000 \\
\hline
\end{tabular}


$\mathrm{NJ} / \mathrm{MP} / \mathrm{ML}$

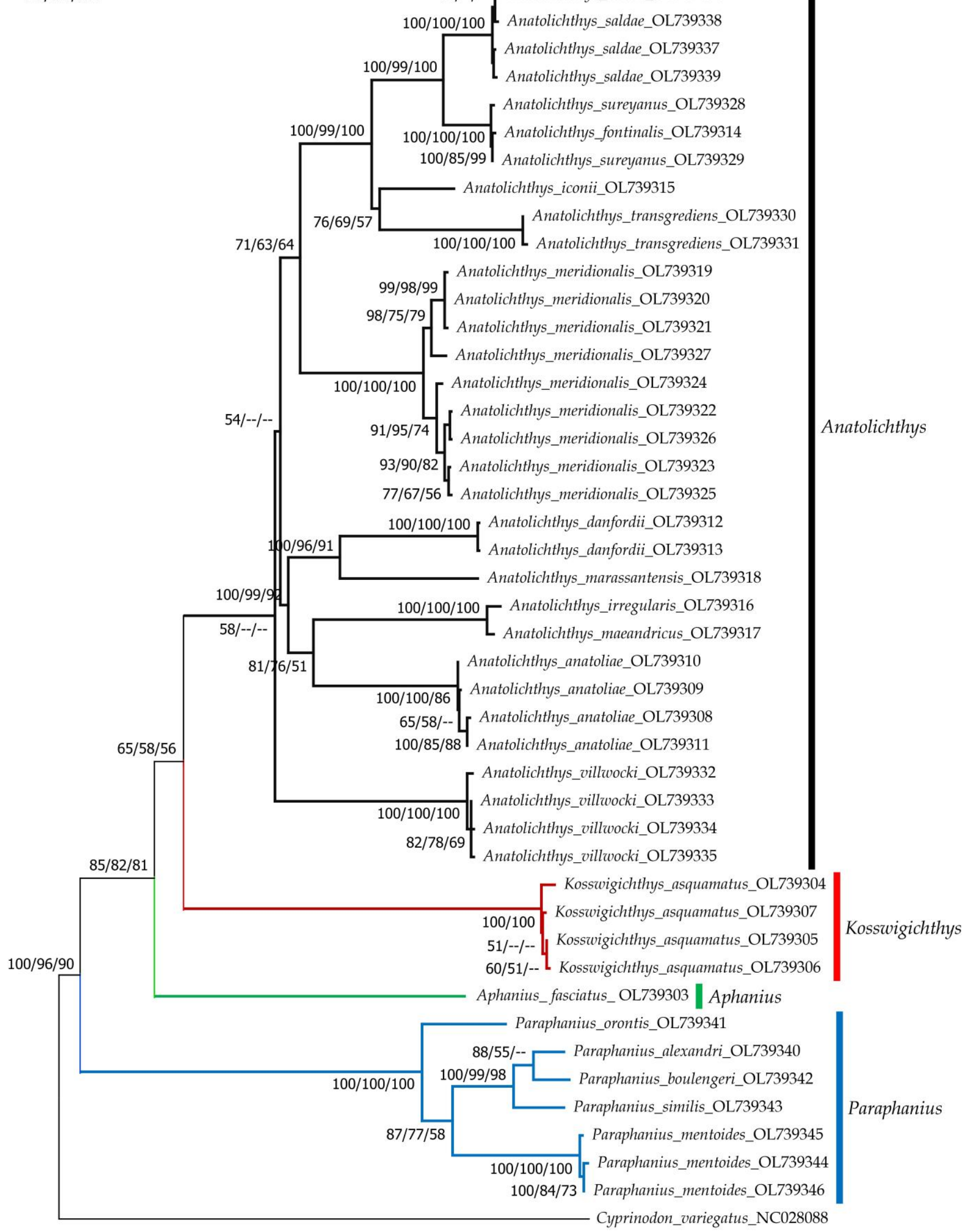

0,050

Figure 1. NJ phylogenetic tree generated based on the mitochondrial $c y t b$ gene. NJ, MP, and ML methods yielded the same topologies, and therefore only the $\mathrm{NJ}$ tree is shown. The bootstrap values are indicated on nodes (NJ/MP/ML). 


\section{DISCUSSION AND CONCLUSION}

The sample size of our study was limited in order to protect populations, as most of the Aphaniids are threatened with extinction according to the IUCN (The International Union for Conservation of Nature) Red List. Therefore, a sufficient number of samples could not be collected from some locations. Aphaniids are represented in Anatolia by four genera (Aphanius, Kosswigichthys, Anatolichthys and Paraphanius). Nineteen out of 21 valid species distributed in Anatolia according to the literature were used in this study. A. splendens, which was recorded only from Lake Gölcük, could not be included in our study because it is probably extinct (Freyhof \& Yogurtcuoglu, 2020). Aphanius almiriensis could not be sampled during fieldwork.

The partial cytb gene (1065 bp) of mitochondrial DNA was sequenced for 107 specimens of 19 aphaniid species distributed in Anatolia. Forty-four $c y t b$ haplotypes, all species-specific, were obtained from this dataset.

A pattern in which nucleotide transitions are favored several-fold over transversions is common in molecular evolution (Stoltzfus \& Norris, 2015). This theory suggests that selection on proteins plays at least a minor role in the observed bias. Therefore, the $\mathrm{Ti} / \mathrm{Tv}$ ratio, which is often greater than 0.5 , has been used as an important parameter such as phylogenetic tree construction and estimation of divergence (Wang et al., 2015). It is also a way to measure the degree of multiple base substitution that has occurred since the common ancestor of the two sequences (Kocher \& Stepien, 1997). Ti/Tv ratio (2.36), which was calculated for the present dataset, is consistent with studies (e.g., Jacquier, et al., 2013; Bloom, 2014; Firnberg, et al., 2014) that provide direct evidence on the relative conservativeness of transitions and transversions that change amino acids and therefore, Anatolian Aphaniid species indicate a relatively low level of genetic variation. High haplotype diversity and low nucleotide diversity determined for Aphaniid species ( $K$. asquamatus, A. anatoliae, A. danfordii, A. meridionalis, A. saldae, A. sureyanus, $A$. transgrediens, $A$. villwocki and $P$. mentoides) distributed in Central Anatolia (Table 2) can be explained by the fact that populations of species distributed in the Central Anatolian plateau including the Göller district, which is known to occur more recently than in other geographical regions, may have exhibited a rapid population expansion and mutation accumulation following the genetic bottleneck. In fact, the evolutionary history of the Anatolian Pseudophoxinus (Hrbek et al., 2004) and Aphanius anatoliae (Hrbek et al., 2002) species complexes is nearly identical. It is thought that the low haplotype and nucleotide diversity values determined for the other Anatolian aphaniid species may be due to the insufficient number of samples.

It was found that the genetic distance values (Table 4) among Aphaniid species were compatible with both the genetic relationship model suggested by Bardakçı et al., (2004) based on RAPD analysis, and the genetic distance values obtained from the analysis of the Aphanius species complex based on 2 ribosomal RNA gene sequences by Hrbek et al., (2002). The genetic distances between Anatolichthys fontinalis - Anatolichthys sureyanus $(0.13 \%$, Table 4) and Anatolichthys maeandricus - Anatolichthys irregularis $(0.57 \%$, Table 4$)$ are very low compared to other species, indicating that these species diverged recently.

Phylogenetic trees, which were constructed using three different algorithms (ML, MP, and NJ), exhibited largely consistent phylogenies for the Aphaniid species. These topologies showed that Anatolian Aphaniid species included four lineages corresponding to genera (Anatolichthys, Paraphanius, Aphanius, and Kosswigichthys), with high bootstrap values (Figure 1) and that is largely consistent with known phylogenetic relationships (Hrbek et al., 2002; Hrbek \& Meyer, 2003; Esmaeili et al., 2020; Freyhof \& Yogurtçuoğlu, 2020). In addition, the mean genetic distance between these four genera varies between $16.6 \%$ (Anatolichthys) and $23.1 \%$ (Paraphanius), supporting phylogenetic lineages that are monophyletic. The genera Aphanius and Kosswigichthys could not be tested because they are represented by a single taxon. A. fontinalis, A. sureyanus, A. maeandricus, and A. irregularis are closely related in the phylogenetic tree, consistent with genetic distance results (Figure 1).

While the tooth-carp specimens of Konya Beşgöz pond differed from all other tooth-carp species in the nearby geographically located lakes region, they clustered together with the specimens from the type locality of $A$. villwockii described by Hrbek and Wildekamp (2003) in the Sakarya basin (Figure 1). The fact that Freyhof (2014) previously reported that $A$. villwocki has distributed in Sakarya River and Ilgin Lake also supports this close relationship. Also, Geiger et al. (2014) reported a very recent biogeographic connection between the Sakarya River and Ilgin Lake basins, and stated that Alburnus nasreddini and Squalius recurvirostris in Ilgın Lake are more closely related to $S$. pursakensis and A. escherichii in Sakarya River. In addition, Aksu and Bektaş (2019) determined that $G$. fahrettini, which was identified from Lake Ilgın, is expected to be genetically close to other species in the Göller district (which is geographically closer to Lake Ilgin), and is closely related to it. $G$. sakaryaensis from the Sakarya River basin (geographically further away from Ilgin Lake). This phenomenon can be explained by the possibility of connecting the Upper 
Sakarya Basin to the Ilgin Lake basin by a large freshwater paleo lake that continued until the upper Neogene period in Central Anatolia (Popov et al., 2004).

Turkey is a speciation center for the family Aphaniidae, as it has 19 species and a high rate of endemism. However, the species belonging to this ecologically important family have become unable to survive due to various factors. Anatolian aphaniids are threatend by climate change (1), food pollution by chemical pesticides and fertilizer waste in wetlands (2), destruction of reeds and wetlands, which are their habitat for irrigation projects (3). In addition, invasive species such as the mosquito fish Gambusia holbrooki, introduced in Turkey as part of biological control against mosquitoes, have a bit of competition, predation, and aggression pressure on Anatolian Aphaniids. Aphanius splendens is already extinct. As a result, most aphaniid species are listed as threatened on the IUCN Red List. Because variable environmental conditions can influence species dispersal capacity and population structure (Schönhuth et al., 2003; Whitehead, 2009), the determination of species diversity, phylogenetic relationships, and distribution areas are necessary for the development of in situ conservation strategies.

\section{ACKNOWLEDGEMENTS}

We thank to Davut Turan (Rize), Fahrettin Küçük (Isparta), Baran Yoğurtçuoğlu (Ankara), Esra Bayçelebi (Rize), Cüneyt Kaya (Rize) and Salim Serkan Güçlü (Isparta) for their assistance in the fieldwork and species identification.

\section{REFERENCES}

Aksu, I. \& Bektas, Y. (2019). Mitochondrial phylogeny and biogeography of the genus Gobio (Teleostei: Cyprinidae) in Turkey. Zoology in the Middle East, $\quad \mathbf{6 5}(2), \quad 128-141 . \quad$ DOI: 10.1080/09397140.2019.1586126

Anderson, S., Bankier, A.T., Barrell, B.G., de Bruijn, M.H.L., Coulson, A.R., Drouin, J., Eperon, I.C., Nierlich, D.P., Roe, B.A., Sanger, F., Schreier, P.H., Smith, A.J.H., Staden, R. \& Young, I.G. (1981). Sequence and organization of the human mitochondrial genome. Nature, 290, 457-465.

Bardakçı, F., Tatar, N. \& Hrbek, T. (2004). Genetic relationships between Anatolian species and subspecies of Aphanius Nardo, 1827 (Pisces, Cyprinodontiformes) based on RAPD markers. Biologia, 59(5), 559-566.

Bloom, J.D. (2014). An experimentally determined evolutionary model dramatically improves phylogenetic fit. Molecular Biology and
Evolution, 31, 1956-1978. $\quad$ DOI: 10.1093/molbev/msu173

Coad, B.W. (2000). Distribution of Aphanius species in Iran. Journal of the American Killifish Association, 33, 183-191.

Esmaeili, H.R., Teimori, A., Zarei, F. \& Sayyadzadeh, G. (2020). DNA barcoding and species delimitation of the Old World tooth-carps, family Aphaniidae Hoedeman, 1949 (Teleostei: Cyprinodontiformes). Plos One, 15, 1-26. DOI: 10.1371/journal.pone.0231717

Firnberg, E., Labonte, J.W., Gray, J.J. \& Ostermeier, M. (2014). A Comprehensive, HighResolution Map of a Gene's Fitness Landscape. Molecular Biology and Evolution, 31, 1581-1592. DOI: $10.1093 / \mathrm{molbev} / \mathrm{msu} 081$

Freyhof, J. \& Yoğurtçuoğlu, B. (2020). A proposal for a new generic structure of the killifish family Aphaniidae, with the description of Aphaniops teimorii (Teleostei: Cyprinodontiformes). Zootaxa, 4810(3), 421-451. DOI: 10.11646/zootaxa.4810.3.2

Freyhof, J. (2014). Aphanius danfordii, The IUCN Red List of Threatened Species. Version 2014.3.

Geiger, M.F., Herder, F., Monaghan, M.T., Almada, V., Barbieri, R., Bariche, M., Berrebi, P., Bohlen, J., Casal-Lopez, M., Delmastro, G.B., Denys, G.P.J., Dettai, A., Doadrio, I., Kalogianni, E., Kärst, H., Kottelat, M., Kovačić, M., Laporte, M., Lorenzoni, M., Marčić, Z., Özuluğ, M., Perdices, A., Perea, S., Persat, H., Porcelotti, S., Puzzi, C., Robalo, J., Šanda, R., Schneider, M., Šlechtová, V., Stoumboudi, M., Walter, S. \& Freyhof, J. (2014). Spatial heterogeneity in the Mediterranean Biodiversity Hotspot affects barcoding accuracy of its freshwater fishes. Molecular Ecology Resources, 14, 1210-1221. DOI: 10.1111/1755-0998.12257

Gholami, Z., Esmaeili, H.R., Erpenbeck, D. \& Reichenbacher, B. (2014). Phylogenetic analysis of Aphanius from the endorheic Kor River basin in the Zagros Mountains, southwestern Iran (Teleostei: Cyprinodontiformes: Cyprinodontidae). Journal of Zoological Systematics and Evolutionary Research, 52, 130141. DOI: 10.1111 /jzs. 12052

Guindon, S. \& Gascuel, O. (2003). A simple, fast, and accurate algorithm to estimate large phylogenies by maximum likelihood. Systematic Biology, 52(5), 696-704. DOI: $10.1080 / 10635150390235520$

Hall, T.A. (1999). BioEdit: A user-friendly biological sequence alignment editor and analysis program for Windows 95/98/NT. Nucleic Acids Symposium Series, 41, 95-98.

Hrbek, T. \& Meyer, A. (2003). Closing of the Tethys Sea and the phylogeny of eurasian killifishes (Cyprinodontiformes: Cyprinodontidae). Journal of Evolution Biology, 16, 17-36. DOI: 10.1046/j.1420-9101.2003.00475.x 
Hrbek, T. \& Wildekamp, R.H. (2003). Aphanius villwocki, a new species from the Sakarya basin of central Anatolian plain, Turkey (Teleostei: Cyprinodontiformes). Ichthyological Exploration of Freshwaters, 14 (2), 137-144.

Hrbek, T., Küçük, F., Frickey, T., Stölting, K. N., Wildekamp, R. H. \& Meyer, A. (2002). Molecular phylogeny and historical biogeography of the Aphanius (Pisces, cyprinodontiformes) species complex of Central Anatolia, Turkey. Molecular Phylogenetics and Evolution, 25, 125137. DOI: 10.1016/s1055-7903(02)00203-8

Hrbek, T., Stölting, K.N., Bardakçı, F., Küçük, F., Wildekamp, R.H. \& Meyer, A. (2004). Plate tectonics and biogeographical patterns of the Pseudophoxinus (Pisces: Cypriniformes) species complex of central Anatolia, Turkey. Molecular Phylogenetics and Evolution, 32, 297-308. DOI: 10.1016/j.ympev.2003.12.017

Jacquier, H., Birgy, A., Le Nagard, H., Mechulam, Y., Schmitt, E., Glodt, J., Bercot, B., Petit, E., Poulain, J., Barnaud, G., Gros, P.A. \& Tenaillon, O. (2013). Capturing the mutational landscape of the betalactamase TEM-1. Proceedings of the National Academy of Sciences of the United States of America, 110, 1306713072. DOI: 10.1073/pnas.1215206110

Kimura, M. (1980). A simple method for estimating evolutionary rates of base substitutions through comparative studies of nucleotide sequences. Journal of Molecular Evolution, 16, 111-120.

Kocher, T.D. \& Stepien, C.A. (1997). Overview of the Classification and Phylogeny of Fishes. 29-30 s. T.D. Kocher and, C.A. Stepien (ed), Molecular Systematics of Fishes, 1997, Academic Press, ISBN: 9780080536910, 314s.

Kosswig, C. (1967). Tethys and its relation to the periMediterranean faunas of freshwater fishes. In: C.G. Adams \& Ager, D.V., (Eds.), Aspects of Tethyan biogeography. Systematics Association Publication, 313-324pp.

Kumar, S., Stecher, G., Li, M., Knyaz, C. \& Tamura, K. (2018). MEGA X: Molecular evolutionary genetics analysis across computing platforms. Molecular Biology, 35, 1547-1549. DOI: 10.1093/molbev/msy096

Librado, P. \& Rozas, J. (2009). DnaSP v5: A software for comprehensive analysis of DNA polymorphism data. Bioinformatics, 25, 1451-1452. DOI: 10.1093/bioinformatics/btp187

Popov, S. V., Rögl, R., Rozanov, A. Y., Steininger, F. R., Shcherba, I. G. \& Kovac, M. (Eds) (2004). Lithological-Paleogeographic maps of Paratethys. 10 maps Late Eocene to Pliocene. Courier Forschungsinstitut Senckenberg, 250, 1-46. ISBN 978-3-510-61370-0.

Por, F.D. \& Dimentman, C. (1989). The legacy of Tethys. An aquatic biogeogaphy of the Levant. Monographiae Biologicae, 165-168.
Posada, D. (2008). jModelTest: phylogenetic model averaging. Molecular Biology and Evolution, 25(7), 1253-1256. DOI: 10.1093/molbev/msn083

Reichenbacher, B., Sienknecht, U., Küchenhoff, H. \& Fenske, N. (2007). Combined otolith morphology and morphometry for assessing taxonomy and diversity in fossil and extant killifish (Aphanius, Prolebias). Journal of Morphology, 268, 898-915. DOI: $10.1002 /$ jmor.10561

Schönhuth, S., Luikart, G. \& Doadrio, I. (2003). Effects of a founder event and sup-plementary introductions on genetic variation in a captive breeding popu-lation of the endangered Spanish killifish. Journal of Fish Biology, 63, 1538-1551. DOI: 10.1111/j.1095-8649.2003.00265.x

Swofford, D.L. (2003). PAUP. Phylogenetic Analysis Using Parsimony. Version 4. Sinauer Associates, Sunderland, Massachusetts.

Teimori, A., Esmaeili, H.R., Hamidan, N. \& Reichenbacher, B. (2018). Systematics and historical biogeography of the Aphanius dispar species group (Teleostei: Aphaniidae) and description of a new species from Southern Iran. Journal of Zoological Systematics and Evolutionary Research, 56, 579-598. DOI: $10.1111 /$ jzs. 12228

Thompson, J.D., Higgins, D.G. \& Gibson, T.J. (1994). CLUSTAL W: improving the sensitivity of progressive multiple sequence alignment through sequence weighing, position-specific gap penalties and weight matrix choice. Nucleic Acid Research, 22, 4673-4680. DOI: 10.1093/nar/22.22.4673

Wang, J., Raskin, L., Samuels, D.C., Shyr, Y. \& Guo, Y. (2015). Genome measures used for quality control are dependent on gene function and ancestry, Bioinformatics, 31(3), 318-323. DOI: 10.1093/bioinformatics/btu668

Whitehead, A. (2009). Comparative mitochondrial genomics within and among species of killifish. BMC Ecology and Evolution, 9, 11. DOI: 10.1186/1471-2148-9-11

Wildekamp, R.H., Küçük, F., Ünlüsayın, M. \& Neer, W.V. (1999). Species and subspecies of the genus Aphanius Nardo, 1827 (Pisces, Cyrinodontidae) in Turkey (Received; 1996). Turkish Journal of Zoology. 23, 23-44.

Wildekamp, R.H. (1993). A World of Killies, Atlas of the Oviparous Cyprinodontiform Fishes of the World, Volume I, The Genera Adamas, Adinia, Aphanius, Aphyoplatys and Aphyosemion. Published by the American Killifish Association, Inc., 311p, U.S.A. 